\title{
José Veríssimo e os “inconvenientes” de suas leituras estadunidenses da guerra civil no México (1913-1914)
}

\author{
Natally Vieira Dias ${ }^{1}$
}

\begin{abstract}
RESUMO: $\mathrm{O}$ artigo analisa as intervenções públicas realizadas pelo educador e crítico literário brasileiro José Veríssimo a respeito da guerra civil desencadeada no México em 1910. Veríssimo era, na época, um dos principais intelectuais brasileiros e um dos poucos que se dedicavam sistematicamente ao estudo da cultura hispano-americana. Foi precisamente a partir de uma coluna sobre o tema, publicada no jornal carioca $O$ Imparcial, que o intelectual brasileiro veiculou uma série de artigos sobre os primeiros anos da Revolução Mexicana. Mostramos que Veríssimo fez da produção jornalística e historiográfica estadunidense a principal fonte de suas análises sobre a situação mexicana e damos destaque ao fato de que a mudança de seu posicionamento sobre o processo revolucionário mexicano implicou num significativo realinhamento em relação à produção estadunidense, ainda que esta tenha se mantido como a principal base para suas intervenções públicas sobre o México revolucionário.
\end{abstract}

PALAVRAS-CHAVE: Revolução Mexicana; Intelectuais; Imprensa.

\section{José Veríssimo and the "inconveniences" of his American readings of civil war in Mexico (1913-1914)}

\begin{abstract}
This article analyzes the public interventions by the Brazilian educator and literary critic Jose Veríssimo about the civil war started in Mexico in 1910. Veríssimo was one of the main Brazilian intellectuals and one of the few, in the period, who devoted works on Hispanic American culture. It was in a column dedicated to the subject, published by a Rio de Janeiro's newspaper, $O$ Imparcial, that Veríssimo had written a series of articles about the early years of the Mexican Revolution. This work shows that American journalistic and historiographical production was the main sources of Veríssimo's analysis on Mexican situation. It focus on the fact that there was a change in his vision on Mexican Revolution, which resulted in a significant realignment in relation to the American production, although it has remained as the main basis for his public interventions about the revolutionary Mexico.
\end{abstract}

KEY WORDS: Mexican Revolution; Intellectuals; Press.

Artigo recebido em: 31/10/2016

Artigo aprovado para publicação em: 21/01/2017

\footnotetext{
1 Doutora em História. Professora Adjunta da Universidade Estadual de Maringá (UEM). Artigo relacionado à tese de doutorado intitulada A Revolução Mexicana nos debates político-intelectuais brasileiros: projeções, leituras e apropriações (1910-1941), defendida em 2015 na Universidade Federal de Minas Gerais, com financiamento parcial da CAPES.

Endereço: Universidade Estadual de Maringá - Campus Regional do Vale do Ivaí

Praça Independência, no 385 - Centro

CEP: 86870-000 - Ivaiporã - Paraná

E-mail: natyvidas@gmail.com
}

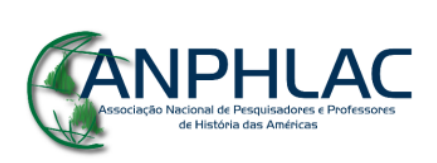

Revista Eletrônica da ANPHLAC, ISSN 1679-1061, №. 22, p. 202-230, Jan./Jun., 2017.

http://revista.anphlac.org.br 
Os episódios dos primeiros anos da Revolução Mexicana tiveram uma ampla e rápida repercussão internacional por meio da imprensa, principalmente através da publicação de notas telegráficas veiculadas pelas agências de notícias. No caso do Brasil, inúmeras dessas notas foram publicadas por grandes jornais dos principais centros urbanos do país desde a intensificação do movimento pela derrubada da ditadura de Porfirio Díaz, em fins de 1910, de forma que a guerra civil no México tornou-se o principal assunto do exterior noticiado pela grande imprensa brasileira antes do início da Guerra Mundial, em 1914. ${ }^{2}$

Inicialmente, essa repercussão tomou a forma de uma verdadeira avalanche de notas curtas, fragmentárias e de conteúdo em grande medida controverso, que era o padrão básico das notícias fornecidas pelas agências internacionais de notícias, ou seja, o "padrão do "fato"”. Como mostra o teórico da comunicação Maurice Mouillaud (1997), há uma relação estreita entre forma e conteúdo no discurso da imprensa, sendo que esse padrão informacional, que é "normatizado e controlado" pelas agências de notícias, tende a submeter os mais diversos tipos de acontecimento a um mesmo formato, obedecendo ao princípio da agilidade. Disso decorre um discurso de caráter fragmentado e descontextualizado, visto que a informação, na forma do "fato", é priorizada em detrimento da análise. (MOUILLAUD, 1997, p. 32-35)

Mas os jornais brasileiros rapidamente passaram a abordar a situação mexicana também por meio da publicação de editoriais e artigos assinados por seus colaboradores. Esses artigos tenderam a funcionar, então, como contextualizadores das informações publicadas sobre o México, na medida em que se propunham a analisar de forma detida o contexto mais amplo do qual decorriam os eventos noticiados brevemente por meio das notas telegráficas.

Algumas das análises mais sistemáticas da Revolução Mexicana que foram veiculadas pela grande imprensa brasileira ainda no período da guerra civil foram produzidas pelo educador e crítico literário José Veríssimo e publicadas pelo jornal carioca O Imparcial (OI), entre 1913 e 1914. Esse conjunto de textos, fruto de sua colaboração com o referido diário, é o objeto de análise deste artigo e a perspectiva historiográfica assumida para o tratamento do assunto vincula-se ao campo da História Intelectual.

\footnotetext{
${ }^{2}$ Consultar a respeito: DIAS, 2015, cap. 1. Para uma visão comparativa com a repercussão dos primeiros anos da Revolução Mexicana na imprensa argentina, cf. DIAS, 2009.
}

\section{GANPHLAC}


Nossa compreensão de “intelectuais" identifica-se com uma definição mais elástica e menos normativa que permite incluir as mais diversas figuras do mundo cultural, "sejam escritores ou artistas, criadores ou difusores [culturais], eruditos, expertos ou ideólogos", desde que desempenhando o "papel que os torna socialmente mais visíveis: atores do debate público, o intelectual como ser cívico." (ALTAMIRANO, 2010, p. 9) É nesse sentido que compartilhamos da proposta de Carlos Altamirano para a definição dos intelectuais enquanto "uma espécie moderna", cuja palavra interpela a opinião pública e os escritos são indissociáveis da ação, sendo a própria escrita concebida enquanto uma ação política. (ALTAMIRANO, 2005 e 2006)

Tal definição pressupõe a compreensão de que os textos produzidos pelos intelectuais se constituem propriamente em "atos discursivos", estando carregados de intenções e objetivos que somente são dimensionáveis quando conseguimos desvendar o contexto argumentativo que deu origem a tais escritos. É o que buscamos realizar ao analisar os artigos de Veríssimo sobre o México revolucionário, aproximando-nos metodologicamente da proposta contextualista de Quentin Skinner (2002).

\section{Veríssimo e o "México bárbaro" de Turner}

As reflexões de José Veríssimo sobre a Revolução Mexicana foram publicadas num período particularmente crítico do processo revolucionário no México, quando o conflito interno ameaçava desdobrar-se em uma guerra internacional com os Estados Unidos. Entre fins de 1913 e meados de 1914, a intervenção estadunidense na guerra civil mexicana extrapolou as vias diplomáticas - que incluíram um "ultimato" do presidente Wilson à renúncia de Victoriano Huerta, líder das forças neoporfiristas que havia subido ao poder no México através do assassinato do presidente Madero -, chegando a se manifestar propriamente na forma de uma intervenção militar, com o desembarque de seus marines no porto mexicano de Vera Cruz em abril de 1914.

Em meio a esse panorama de crescentes tensões entre os países do norte, Veríssimo passou a concentrar suas atenções na situação mexicana e seus desdobramentos internacionais, embora esse assunto não se enquadrasse exatamente no perfil do espaço em que publicava seus artigos no jornal carioca. O intelectual brasileiro escrevia para OI como comentador da cultura e particularmente da literatura hispano-

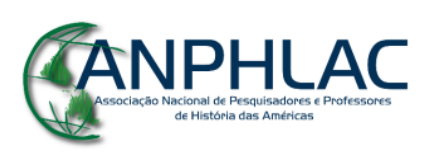

Revista Eletrônica da ANPHLAC, ISSN 1679-1061, №. 22, p. 202-230, Jan./Jun., 2017.

http://revista.anphlac.org.br 
americana, mas a continuidade e a intensificação da guerra civil no México fizeram com que ele se desviasse dos temas habituais e concentrasse sua atenção no drama mexicano, o que procurou justificar aos leitores em fins de 1913, afirmando: "tem estado, e ainda continua, muito em foco o México.” (VERÍSSIMO, O Imparcial, 13/09/1913, p. 2)

Entre as fontes utilizadas por José Veríssimo em suas argumentações sobre a Revolução Mexicana destacaram-se artigos produzidos nos Estados Unidos, tanto textos publicados pela grande imprensa quanto por revistas especializadas. No primeiro artigo que publicou sobre o México revolucionário no jornal carioca, em setembro de 1913, Veríssimo explicitou que tomava como base para suas reflexões as análises desenvolvidas pelo jornalista estadunidense John Kenneth Turner, mais particularmente em um artigo veiculado pelo periódico Metropolitan Magazine, de Nova York, naquele mesmo ano.

Nesse momento, Turner já era bastante conhecido por seu Barbarous Mexico, coletânea de artigos e fotografias de caráter denuncista sobre a situação de miséria e exploração dos camponeses mexicanos durante o porfiriato, produzida a partir de uma longa permanência no México, entre meados de 1908 e inícios de 1909. Embora os textos do jornalista estadunidense só tenham sido compilados na forma de livro nos Estados Unidos no início de 1911, o livro conheceu uma edição anterior realizada na Inglaterra em dezembro de 1910 e teve vários de seus artigos publicados na imprensa estadunidense desde 1909. (MEYER, 2005, p. 41)

Sobre a importância dos artigos de Turner, que contribuíram para "lançar lenha na fogueira" da mobilização que daria início à Revolução Mexicana em fins de 1910, a historiadora mexicana Eugenia Meyer defende a ideia de que o "jornalismo beligerante" de Turner exerceu um papel desvendador: "no fim das contas", ele "ofereceu uma visão de conjunto do que era o México no período imediatamente anterior à Revolução", o que colocou "socialistas, liberais e conservadores frente a uma caixa de Pandora que guardava muitas surpresas [...] e que, sem dúvida, provocaria uma reação crítica ao sistema." (MEYER, 2005, p. 46)

Em 1913, o artigo de Turner What is the Matter in México? apareceu na Metropolitan Magazine de Nova York e foi citado por José Veríssimo em $O$ caso do México, publicado em OI no mesmo ano. Na ocasião, o estadunidense foi apresentado

\footnotetext{
${ }^{3}$ As traduções de obras e documentação em língua estrangeira são da autora do presente artigo.

\section{GANPHLAC}


pelo brasileiro como "uma autoridade em questões mexicanas, por ter estudado o país de primeira mão, sendo, como nenhum escritor, qualificado para explicar as condições do México.” (VERÍSSIMO, O Imparcial, 13/09/1913, p. 2) Nesse período, a principal tribuna de Turner já era o semanário Appeal to Reason, conhecido como "guarida de revoltosos e refúgio de líderes operários e exilados políticos", sendo bastante conhecidas suas vinculações com o socialismo estadunidense e com os líderes anarquistas mexicanos que se encontravam exilados nos Estados Unidos e em franca atuação a partir daquele país. (MEYER, 2005, p. 39) As opiniões de Turner eram, portanto, bastante divergentes e críticas em relação a uma visão mais conservadora, muito corrente em seu país, a respeito do México e dos mexicanos. E foi exatamente nas análises deste jornalista estadunidense que José Veríssimo buscou apoiar-se para realizar suas primeiras intervenções públicas a respeito da Revolução Mexicana.

Inicialmente, Veríssimo procurou descartar, a reboque de Turner, as visões depreciativas do suposto "caráter mexicano". Derivado de teorias racialistas, esse argumento encontrava-se muito presente em análises sobre o México realizadas por autores norte-americanos e foi recorrentemente rebatido pelo próprio Turner. ${ }^{4} \mathrm{Na}$ mesma direção do jornalista estadunidense, Veríssimo fez questão de afirmar de maneira explícita sua compreensão de que "o caso do México [...] não e[ra] racional[,] [sic] mas social.” (VERÍSSIMO, O Imparcial, 13/09/1913, p. 2) O sentido dessa afirmação era afastar-se da concepção de que a eclosão do movimento revolucionário e o prolongamento da guerra civil no México se explicavam por uma suposta incapacidade dos mexicanos para a democracia. Contra essa percepção da situação mexicana, Veríssimo argumentou, ancorado no "México bárbaro" traçado por Turner, que a grande causa da instabilidade política mexicana era a situação social que predominava no país.

O brasileiro se apoiou nas análises do jornalista estadunidense para explicar os problemas sociais do México a partir da noção de "feudalismo mexicano". Na

\footnotetext{
${ }^{4}$ Em diversos artigos, Turner explicita a intenção de reparar as más interpretações sobre o caráter dos mexicanos veiculadas pela imprensa de seu país. Um exemplo emblemático encontra-se em "Mexico's Bandit Armies", artigo publicado em The National Weekly, em abril de 1913, no qual rebateu a alcunha de "bandidos" muito usada pelos periódicos estadunidenses para se referirem aos revolucionários mexicanos. Em geral, o uso da violência atribuído a estes pelos articulistas estadunidenses aparecia relacionado ao suposto "caráter peculiar de desordem dos latino-americanos". Turner desmentiu tal consideração e defendeu os revolucionários mexicanos, inclusive Zapata, como "patriotas". Uma tradução para o espanhol do artigo consta da compilação organizada por Eugenia Meyer. Cf. TURNER, John Kenneth. Mexico's Bandit Armies. In: MEYER, 2005, p. 205-210.
}

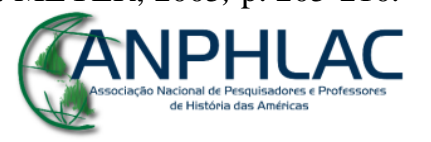

Revista Eletrônica da ANPHLAC, ISSN 1679-1061, №. 22, p. 202-230, Jan./Jun., 2017.

http://revista.anphlac.org.br 
perspectiva de Turner, tratava-se de um sistema de concentração agrária que culminava na submissão das autoridades locais aos hacendados e na miséria da maior parte da população. A partir dessa percepção, Veríssimo qualificou a Revolução Mexicana como um movimento de "ideal de reforma mais social que política", como "um espontâneo levante popular para acabar com certas condições intoleráveis, todas oriundas do feudalismo vigente". Diante desse quadro, lançou sua conclusão, também apoiada na argumentação de Turner, de que "somente uma melhoria do problema agrário pode[ria] restituir a paz ao México.” (VERÍSSIMO, O Imparcial, 13/09/1913, p. 2)

Nessa perspectiva, José Veríssimo argumentou que a Revolução Mexicana era "fruto" da ditadura porfirista e que esta havia sido "de todo estéril" porque não tinha sido direcionada "[a]o que mais importava ao progresso do país, [ou seja,] a educação cívica do povo, a sua instrução, a melhoria de suas lastimáveis condições materiais e mentais." (VERÍSSIMO, O Imparcial, 13/09/1913, p. 2) Essa interpretação destoava da visão mais geral que circulava sobre o México porfirista, tomado por muitos como exemplo de modernização e progresso material. Alguns intelectuais latino-americanos, ao apresentarem suas primeiras impressões sobre o início da Revolução Mexicana, manifestaram dificuldade em interpretar o porfiriato considerando que, apesar do inegável autoritarismo político, havia que se levar em conta a modernização operada por esse mesmo regime. ${ }^{5}$

José Veríssimo, em seu posicionamento absolutamente crítico do regime porfirista, demonstrava uma percepção distinta de progresso, menos ancorada em expressões materiais e tendo como cerne a educação "do povo". Tratava-se da visão de um típico representante do pensamento republicano brasileiro em sua vertente

\footnotetext{
${ }^{5}$ Essa foi, por exemplo, a perspectiva assumida por Manoel de Oliveira Lima que, assim como Veríssimo, publicou na grande imprensa diversos artigos, desenvolvendo interpretações sistemáticas a respeito da Revolução Mexicana em seus primeiros anos. No primeiro artigo sobre o México revolucionário que publicou como colaborador de $O$ Estado de São Paulo, Oliveira Lima identificou o movimento revolucionário como "fruto" da ditadura porfirista e criticou contundentemente os métodos políticos do ditador mexicano; mas não deixou de reputar a esse mesmo regime o desenvolvimento material do país. Em sua visão, sob a ditadura de Porfirio Díaz, o México "desenvolveu consideravelmente seus recursos, alcançando notável grau de prosperidade e de crédito, e até a reputação de uma nação organizada, estável e progressiva". (OESP, 27/05/1911, p. 3) Ambiguidade semelhante na avaliação do porfiriato aparece na intervenção dos editores do diário argentino La Prensa, entre os quais se encontrava Estanislao Zeballos. A dificuldade em avaliar o regime e o ditador mexicano é ali explicitamente manifesta ao apresentarem Porfirio Díaz como um "mandatário, que durante trinta anos governou o México, fazendo irrisórias as práticas republicanas". Entretanto, destacam os editores portenhos: "é muito difícil julgá-lo com critério desapaixonado, mas não se pode deixar de reconhecer que realizou grandes e positivos progressos em sua pátria." (La Prensa, 19/05/1911, p. 11)
}

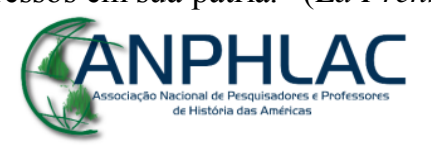

Revista Eletrônica da ANPHLAC, ISSN 1679-1061, №. 22, p. 202-230, Jan./Jun., 2017.

http://revista.anphlac.org.br 
reformista, cuja principal esperança encontrava-se na capacidade regeneradora da educação, vista como instrumento capaz de sanar, ou ao menos atenuar, as desigualdades sociais. ${ }^{6}$ Com essa perspectiva, seu primeiro olhar sobre a situação mexicana esteve colocado na questão social envolvida no processo revolucionário. Foram suas interpretações sobre o drama social mexicano que o levaram, consequentemente, a criticar a situação política sustentada pelo "regime pseudorepublicano" de Porfirio Díaz (VERÍSSIMO, O Imparcial, 13/09/1913, p. 2) E a partir desse ângulo principalmente, ou seja, da questão política, Veríssimo estabeleceu relações explícitas entre a situação mexicana e os dissabores da República brasileira.

\section{Veríssimo e o "espelho" mexicano}

O intelectual brasileiro sugeriu que a situação política do Brasil fosse analisada a partir do "espelho do México", o qual ensinaria que "a educação dos regimes liberais só se faz respeitando escrupulosamente esses regimes"; afinal, como destacou, "não se ensina uma criança a andar ligando-lhe as pernas." (VERÍSSIMO, O Imparcial, 13/09/1913, p. 2) As analogias entre as situações de México e Brasil não pararam por aí. Em um artigo intitulado precisamente Miremo-nos no México, publicado em fevereiro de 1914, Veríssimo tomou como foco a continuidade da guerra civil naquele país e, a partir da análise da situação mexicana, voltou a criticar as elites brasileiras de forma ainda mais contundente. Novamente recorrendo à metáfora do espelho, dessa vez de forma irônica, sugeriu a seus interlocutores que, à luz da situação mexicana, fizessem a seguinte reflexão:

\footnotetext{
Não conhecem os senhores outro [país] em que Constituição, Eleitorado, Congresso, Povo são, como no México, apenas "luzidos palavrões"? Não sabem de um em que também se manda pedir aos governantes os votos precisos para arranjar um presidente [...]? Não lhes é familiar a corrupção administrativa e política de certa terra muito nossa conhecida [...]? Pois mirem-se no espelho do México e com o reflexo da própria imagem nele estampada, verão a que os males de que também padecemos levaram aquele desditoso país. (VERÍSSIMO, O Imparcial, 01/02/1914, p. 2)
}

\footnotetext{
${ }^{6}$ Recordemos que José Veríssimo foi autor do pioneiro estudo A educação nacional, publicado originalmente no Pará, em 1890, logo após a instauração do regime republicano, com o objetivo não apenas de apontar a lastimável situação do ensino no país, mas igualmente propor mecanismos para sua estruturação. Para uma análise sucinta dessa obra, relacionada ao "imenso sentido simbólico" conferido à ideia de República como "construção de uma nova cultura cívica", ver GOMES, 2009, p. 99-105. Consultar também COSTA, 2004.
}

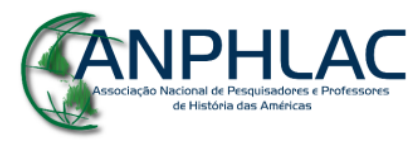


A crítica à deplorável situação política da República brasileira é aqui evidente, bem como a intenção do texto de alertar sobre o perigo de que tal situação desembocasse numa convulsão generalizada da ordem, como ocorria no México. No entanto, o mais relevante a mencionar desta intervenção de Veríssimo é que ela marca uma significativa mudança de perspectiva em suas interpretações sobre o México revolucionário. Embora as publicações norte-americanas tenham permanecido como as principais referências utilizadas por ele para tratar da situação mexicana, suas análises foram progressivamente se afastando de uma perspectiva mais crítica, como a de Turner, para tomar o caminho de algumas opiniões bastante conservadoras e preconceituosas a respeito do México e, de um modo geral, da América Latina.

Quando, no mencionado artigo, Veríssimo se referiu ao México como um país onde "Constituição, Eleitorado, Congresso [e] Povo" não passavam de "luzidos palavrões", na realidade estava citando um reconhecido historiador norte-americano, Albert Bushnell Hart, ao qual se referiu, entre outros elogios, como sendo "um dos mais reputados publicistas norte-americanos" e professor de uma das mais "afamadas" universidades dos Estados Unidos, a Harvard. A interpretação do estadunidense sobre a revolução do México, citada por Veríssimo, havia sido veiculada por meio do artigo Mexico and the Mexicans, publicado em inícios de 1914 na revista The World's Work (TWW) em um número dedicado ao país hispânico da América do Norte, intitulado precisamente All about MEXICO. (TWW, no 3, jan, 1914.) ${ }^{7}$

Convém fazer uma apresentação minimamente pormenorizada da referida edição, pois um panorama mais completo de sua interpretação sobre o México permite compreender melhor a apropriação de um determinado discurso estadunidense realizada por José Veríssimo. O número de TWW dedicado ao México revolucionário trazia mais de uma dezena de artigos sobre o país, vários destes ilustrados, como era o caso do artigo de Hart, citado por Veríssimo. Além deste, outros dois textos presentes na edição merecem ser destacados pelo fato de apresentarem de forma explícita a posição assumida pelo periódico tanto a respeito da política externa estadunidense em relação ao México revolucionário quanto à situação interna mexicana. São eles o editorial $A$

\footnotetext{
${ }^{7}$ Uso de caixa alta no original.

\section{CANPHLAC}

Revista Eletrônica da ANPHLAC, ISSN 1679-1061, №. 22, p. 202-230, Jan./Jun., 2017.

http://revista.anphlac.org.br
} 
marcha dos eventos e um artigo não assinado - portanto, possivelmente também escrito pelos editores - intitulado Carranza.

O referido editorial foi dedicado basicamente a defender os "bons auspícios" do presidente Wilson em relação ao México. Nesse texto, o chefe da Casa Branca foi descrito como um "alinhado contra o destino manifesto, as tendências anglo-saxônicas [e] o poder do dinheiro" e sua posição em relação ao país vizinho entendida como uma "política altruísta", que desconsiderava as prescrições da Doutrina Monroe. Ainda segundo os editores da revista, o presidente dos Estados Unidos estava "fazendo o que pod[ia]" para “manter uma condição 'tolerável' [sic] no México[,] ao reconhecer apenas um governo legalmente eleito." E tudo isso decorreria de "um espírito cristão, tão incomum nas relações entre nações, que e[ra] objeto de incompreensão." (TWW, Editorial, nº 3, jan, 1914, p. 249-50)

O editorial da publicação estadunidense terminava rebatendo as críticas da imprensa, "daqui e de alhures", que acusavam os Estados Unidos de "abusarem" em relação ao México por "não o compreender." Da perspectiva dos editores da revista, era necessário destacar também o "outro lado" na questão: “já é hora dos mexicanos se esforçarem para nos compreender, para compreender o que o governo americano está tentando fazer e cooperar com esses esforços.” (TWW, Editorial, no 3, jan, 1914, p. 250) Essas palavras fechavam o editorial da edição da revista estadunidense dedicada ao México revolucionário.

Ainda no âmbito do editorial, há outro elemento que chama muito a atenção: a publicação de uma foto de Carranza, que aparece localizada exatamente na página ao lado do início do texto, ocupando toda a primeira página da revista. Trata-se de uma foto em que o chefe da vertente constitucionalista aparece sorrindo e sua imagem acompanhada da seguinte legenda: "GENERAL VENUSTIANO CARRANZA. O comandante-em-chefe dos constitucionalistas mexicanos, o pai da revolução maderista e o líder da luta pela vingança de sua morte e continuidade de seu governo." (TWW, Editorial, $\mathrm{n}^{\circ} 3$, jan, 1914, p. 242)

\section{GANPHLAC}




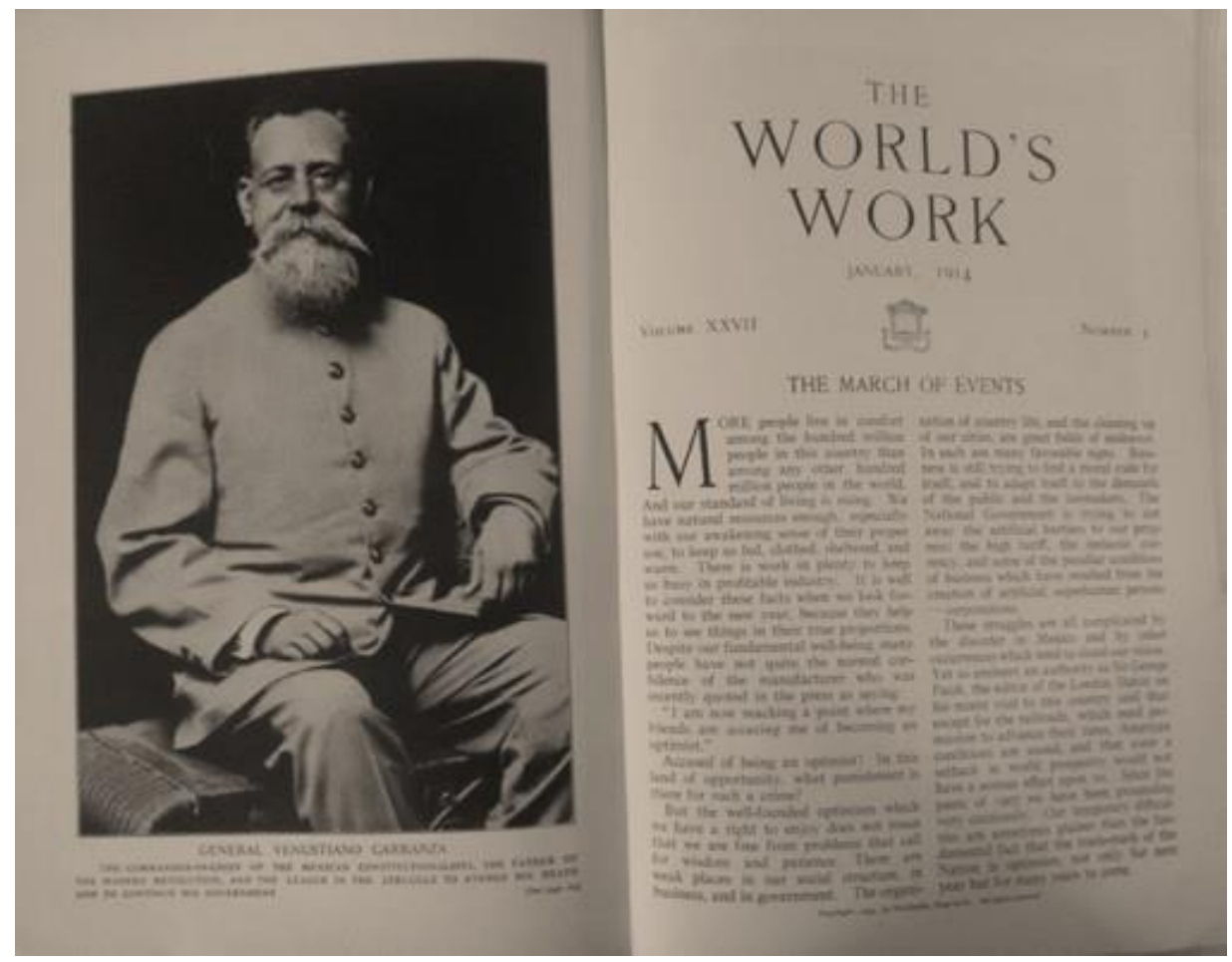

Imagem 1 - General Venustiano Carranza (The World's Work, nº 3, jan, 1914, p. 248)

Além de apresentar o "General Venustiano Carranza", a legenda da imagem remetia o leitor à página do artigo Carranza, no qual o líder revolucionário era apresentado como "o primeiro governador a desafiar Huerta e iniciar a revolta armada que rapidamente espalhou-se pelo norte do México contra o régime [sic] do General Victoriano Huerta.” (TWW, “Carranza”, nº 3, jan, 1914, p. 267-268)

O referido artigo descreve Carranza como pertencente a "uma das mais antigas famílias que ostentam pura ascendência espanhola" e destaca que "Don Venustiano recebeu a educação de um gentleman nas escolas do norte do México.” A parte final do texto afirma reproduzir "uma boa ideia desse homem [Carranza] e seus objetivos", a qual teria sido retirada de uma entrevista concedida pelo mexicano a um correspondente do Times de Londres. Nessa ocasião, Carranza teria afirmado ser "o único líder reconhecido como supremo por todos os chefes da revolução" no México, enquanto o jornalista britânico teria ficado "como que sonhando" - literalmente if I were dreaming - ao ouvir tão "amável [e] erudito cavalheiro" apresentar seu plano de ação, no qual se podia observar sua "profissão de fé na democracia." Entretanto, o artigo da revista estadunidense terminava ressaltando, ainda supostamente citando o periódico britânico, que "a discrepância entre seu discurso [de Carranza] e sua política mostra[va] o quão

\section{GANPHLAC}

Revista Eletrônica da ANPHLAC, ISSN 1679-1061, №. 22, p. 202-230, Jan./Jun., 2017.

http://revista.anphlac.org.br 
distante est[ava] a mentalidade do México daquela existente na Europa e nos Estados Unidos.” (TWW, “Carranza", n 3, jan, 1914, p. 268)

Esses dois artigos, que expressam a visão dos editores da revista estadunidense, guardam uma relação muito forte com o do historiador Albert Bushnell Hart sobre o México e os Estados Unidos que foi amplamente reproduzido por José Veríssimo. Em primeiro lugar, é preciso destacar que o texto de Hart trazia um número imenso de imagens, sendo que 25 fotografias ocupavam as 18 páginas totais do artigo. Além de fotografias de importantes edifícios mexicanos - como a Catedral localizada no Zócalo da Cidade do México, a sede do Serviço Exterior e o Castillo de Chapultepec -, também foram apresentadas ao leitor muitas outras imagens que remetiam aos enormes interesses estrangeiros presentes no México e a situação do país em revolução. A primeira delas, ocupando completamente a segunda página do artigo, retratava um vulcão do estado de Colima e associava a imagem à situação política do país, através da legenda "México em erupção" (imagem 2). Outras fotografias retratavam aspectos como "agricultura primitiva no México", imagem que contrastava com fotos de modernas refinarias e estradas de ferro apresentadas como uma das principais "evidências dos enormes interesses estrangeiros [no país]." (TWW, "Carranza", n 3, jan, 1914, p. 277, 281)

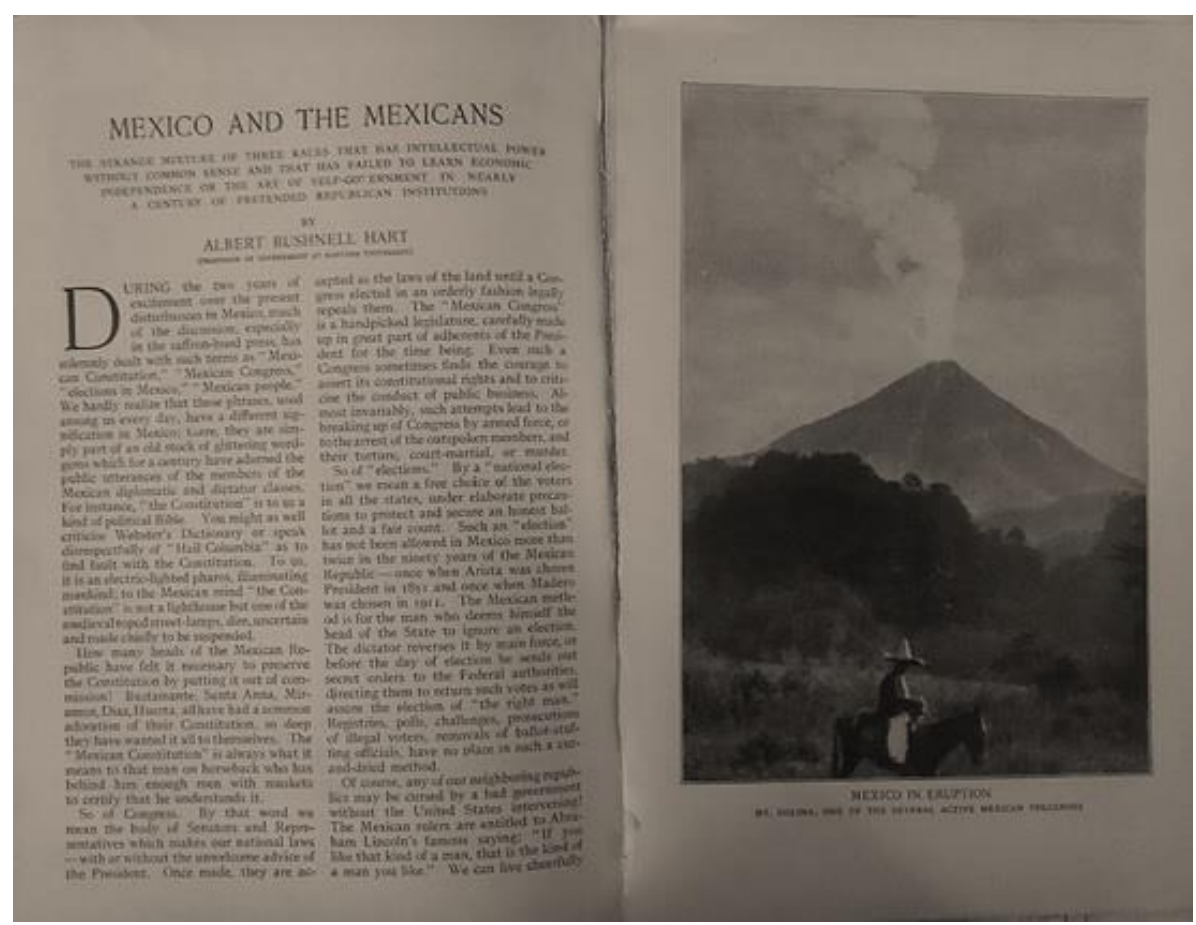

Imagem 2 - Mexico in eruption (The World's Work, no 3, jan, 1914, p. 272-273)

\section{CANPHLAC}

Revista Eletrônica da ANPHLAC, ISSN 1679-1061, №. 22, p. 202-230, Jan./Jun., 2017.

http://revista.anphlac.org.br 
Algumas das imagens reproduzidas no artigo de Hart buscavam mostrar a superioridade bélica dos revolucionários em relação aos soldados federais. Nesse contexto, os revolucionários mexicanos foram identificados com os constitucionalistas, grupo liderado justamente por aquele que tantos elogios recebeu por parte da publicação, D. Venustiano Carranza. Nesse sentido, o discurso da revista estadunidense levava o leitor a identificar os constitucionalistas como o único grupo legítimo no seio do movimento revolucionário mexicano. Por um lado, essa identificação atesta a importância do traquejo político de Carranza - ao conceder entrevistas, posar para fotos e articular um discurso capaz de convencer os estadunidenses de sua capacidade de liderança em meio ao fragmentado movimento revolucionário em seu país - como parte de uma estratégia de projeção internacional que, de fato, tornou-se um elemento decisivo para a ascensão política do constitucionalismo. ${ }^{8}$ Mas, por outro lado, a mencionada identificação dos revolucionários mexicanos com o constitucionalismo também aponta para uma perspectiva estadunidense marcadamente preconceituosa e bastante conservadora que passou a servir de base para as análises de José Veríssimo sobre o México revolucionário.

Nas páginas da revista The World's Work, a legitimação política de Carranza foi construída, primeiramente, por sua identificação racial com os colonizadores espanhóis e, além disso, por sua vinculação com a educação formal, caracterização que afastava completamente sua imagem da luta camponesa, então em plena ascensão no movimento revolucionário mexicano. Apesar disso, o discurso da revista não deixou de atribuir ao chefe constitucionalista a mesma "mentalidade do México" e ressaltar sua “discrepância" em relação à mentalidade estadunidense e europeia. Dessa forma, podese concluir que nem mesmo a pretendida "superioridade" racial e intelectual de Carranza o livrava de uma "mentalidade inferior", sendo, portanto, insuficiente para garantir que ele estabelecesse um governo respeitável em seu país.

A consequência lógica de toda essa argumentação era a ideia de que a única solução para o México estaria na tutela moral de uma nação de "mentalidade superior", que ajudasse "altruisticamente" o país a sair do estado lastimável em que se encontrava. Esse foi precisamente o quadro traçado no artigo de Albert Bushnell Hart, tão elogiado

\footnotetext{
${ }^{8}$ Sobre a propaganda internacional levada a cabo pelos constitucionalistas e a importância dessa estratégia para a consolidação de seu poder no cenário interno da Revolução Mexicana, cf. YANKELEVICH, 1999.
}

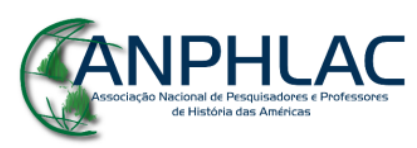

Revista Eletrônica da ANPHLAC, ISSN 1679-1061, №. 22, p. 202-230, Jan./Jun., 2017.

http://revista.anphlac.org.br 
e citado por José Veríssimo. Em seu texto, o historiador estadunidense apresentou uma visão absolutamente desoladora do México - não apenas do período revolucionário, mas de toda a sua trajetória após a independência política - a partir de comparações superficiais e simplistas entre aquele país e o seu próprio.

Segundo Hart, citado por Veríssimo, havia "um século" que expressões como "Constituição mexicana", "Congresso mexicano", "eleições no México" e "povo mexicano" não passavam de "luzidos palavrões" que "enfeita[va]m a loquela $[s i c]$ dos diplomatas e ditadores mexicanos". E tudo isso se passava de maneira inversa ao que ocorria nos Estados Unidos, onde, corroborava Veríssimo, "para os compatriotas do Sr. Hart a Constituição é uma espécie de Bíblia política" e, mais do que isso, "um farol de luz elétrica iluminando a humanidade”. (VERÍSSIMO, IO, 01/02/1914, p. 2)

Ao citar e endossar tal passagem, Veríssimo fazia eco à difundida perspectiva do "excepcionalismo americano", sustentada pelo próprio Hart em seu artigo, bem como no conjunto da edição de The World's Work dedicada ao México revolucionário no início de $1914 .{ }^{9}$ Nesse momento, portanto, o intelectual brasileiro adotava, em relação aos Estados Unidos, uma perspectiva muito distinta daquela que assumira em sua obra A educação nacional, de 1890, na qual dedicou um amplo parágrafo para descrever os "vícios" históricos daquela nação, entre os quais listou a justificação e a exaltação da escravidão “de Bíblia na mão", e inclusive a "corrupção política” que, naquele contexto, tanto “repugna[vam]” seu "senso moral.” (VERÍSSIMO, 2013 [1890], p. 172)

Já em 1914, em seus comentários sobre a situação do México revolucionário, que envolvia de forma latente a delicada questão da relação com os Estados Unidos, não encontramos sequer uma sombra dessa posição crítica em relação à potência continental. Muito ao contrário, Veríssimo não apenas reproduziu a idealizada visão da excepcionalidade estadunidense, como também a perspectiva eminentemente racial

\footnotetext{
${ }^{9}$ Para se ter uma ideia da perspectiva historiográfica assumida por Hart, vale citar seu prefácio ao décimo volume da compilação dos textos de Theodore Roosevelt, editada pela Roosevelt Memorial Association, fundada em 1919, após sua morte. Nesse texto, publicado em 1924 e intitulado Roosevelt as a pionner, Hart se deteve a delinear uma imagem de Roosevelt como "grande homem", um herói nacional que teria prestado inúmeros serviços à nação, estando entre os mais significativos o seu empenho na promoção da "conquista da wilderness", entendida como um processo de "estabelecimento de fundações seguras para a grande República Federal." Embora nesse período o paradigma "progressista" já estivesse consolidado na historiografia estadunidense, como mostra Gerson Moura em seu estudo sobre o tema, a perspectiva assumida por Hart - ao vincular a expansão para o oeste a um personagem específico, um Roosevelt "pioneiro" e "herói nacional" -, encontrava-se muito mais próxima da concepção "romântica", que foi predominante no mundo anglo-saxão durante o século XIX, mas que "teve longa vigência nos Estados Unidos." Cf. MOURA, 1995, p. 15; HART, 1924.
}

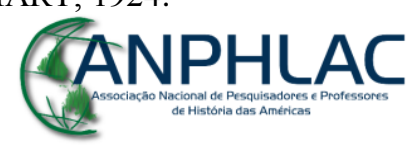


através da qual boa parte dos estadunidenses enxergavam o México e, por extensão, a América Latina. No âmbito da interpretação dos acontecimentos revolucionários no México, descrita por Hart e citada por Veríssimo, o grande fator evocado para explicar a deplorável situação do país em revolução foi exatamente o caráter do "povo mexicano", definido fundamentalmente a partir de parâmetros raciais.

$\mathrm{Na}$ visão do estadunidense, reproduzida pelo brasileiro, os mexicanos não passavam de "um grupo de seres humanos cuja maioria fica[va] tão alheia à vida pública e à atividade nacional como se habitasse a lua". Embora a causa imediata dessa situação tenha sido apontada como a falta da "educação popular [...] que deixa[va] iletrado cinco sextos da população", na concepção do estudioso norte-americano, repetida por Veríssimo, o problema do México tinha relação direta com a "espécie de gente" que o habitava, sendo o país composto em sua maioria por indígenas e mestiços. (VERÍSSIMO, O Imparcial, 01/01/1914, p. 2)

Ao desenvolver seus argumentos com base no caráter racial da população mexicana, o historiador estadunidense chegou a propor a estatística - que foi reproduzida por José Veríssimo - de que "talvez [apenas] a vigésima parte [dos mexicanos] se[ria] pura de mistura com o índio", embora cerca de "um quinto chama[ss]e a si mesmo de espanhol [branco]”. Ainda segundo essa análise, os brancos mexicanos eram os "politicamente dominantes" e, portanto, "cab[ia]-lhes a responsabilidade do péssimo governo do México". Por outro lado, teriam sido "os homens de negócio estrangeiros" - "americanos, espanhóis, ingleses, franceses, alemães", ou seja, também brancos - aqueles "que fizeram o progresso material do México". Toda essa análise racial da situação mexicana desembocava na seguinte questão, formulada pelo estudioso estadunidense e citada por Veríssimo:

é um problema saber até que ponto poderão os mexicanos governar-se. Cada
esforço que há cerca de cem anos fizeram pelo governo de si mesmos (self
government) foi contrariado, ou pelo ditador do momento, ou por alguém que
ambicionava ser o déspota seguinte. (VERÍSSIMO, O Imparcial, 01/01/1914,
p. 2)

Ao referendar tal ponto de vista, Veríssimo se distanciava claramente da perspectiva inicial que assumira em relação ao México, inclinada a atribuir causas sociais à Revolução. O intelectual brasileiro passava, então, a se alinhar a (ou pelo

\footnotetext{
${ }^{10}$ Itálicos e reprodução da expressão em inglês no original.

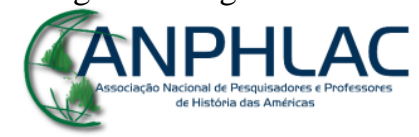

Revista Eletrônica da ANPHLAC, ISSN 1679-1061, №. 22, p. 202-230, Jan./Jun., 2017.

http://revista.anphlac.org.br
} 
menos basear-se em) uma explicação eminentemente racial a respeito dos problemas mexicanos e do movimento revolucionário que se desenvolvia no país. Além disso seria impossível deixar de notar -, a argumentação de Hart sobre a dificuldade, ou mesmo impossibilidade, de autogoverno por parte dos mexicanos não deixava de estar comprometida com a posição intervencionista de seu país no México. ${ }^{11}$

A análise do historiador estadunidense sobre o país revolucionário era propagada exatamente em um momento de graves desentendimentos diplomáticos entre a Casa Branca e o governo reacionário do ditador mexicano Victoriano Huerta, que havia orquestrado o assassinato do presidente Madero. Enquanto Washington pressionava pela renúncia do "usurpador" mexicano, as facções revolucionárias dentro do México repudiavam a intervenção estadunidense nos assuntos internos do país. Nos próprios Estados Unidos, o mesmo John Kenneth Turner, que havia exposto a miséria que assolava os camponeses mexicanos durante o porfiriato, passava, então, a denunciar os intentos "imperialistas" sobre o México por parte de seu país, nos quais, em sua visão, predominavam as articulações entre a política externa e os interesses econômicos dos “piratas de Wall street". (TURNER, Appeal to Reason, 08/11/1913, p. 2)

Enquanto Turner militava, a partir de sua tribuna no Appeal to Reason, para que a opinião pública estadunidense se posicionasse contra a intervenção estadunidense nos assuntos internos mexicanos, por sua parte, o discurso oficial estadunidense buscava dotar a mesma de ares moralistas empunhando, como de costume, a retórica da abnegada missão da "América" no combate às tiranias. Nesse contexto, a referida edição de The World's Work em seu conjunto, e de forma ainda mais incisiva o artigo do historiador Albert Bushnell Hart sobre o "caráter dos mexicanos" - e as virtudes dos

\footnotetext{
${ }^{11}$ A esse respeito, destacamos a posição pessoal de Hart como um defensor da Doutrina Monroe e do corolário rooseveltiano à mesma. São exemplares nesse sentido suas ideias expostas em 1915 nas páginas da tradicional The North American Review, em um artigo intitulado Shall We Defend the Monroe Doctrine? A essa pergunta, levantada não mais que de forma retórica, o historiador estadunidense respondeu enfaticamente que a referida doutrina era "fortemente necessária", devido ao fato de existirem no continente vários países, como o México, por exemplo, que "ainda se encontravam em estado de imperfeita civilização" e que "fornec[iam] exemplos dos sérios impedimentos existentes para a paz na América". O foco de Hart no referido artigo era defender uma expressão mais bélica para a Doutrina Monroe, o que, em sua concepção, deveria incluir "a ampliação das forças militar e naval" e a "centralização dos Departamentos de Guerra e Marinha" dos Estados Unidos em face da ameaça de constantes "revoluções" em países do continente. Ainda segundo o historiador estadunidense, essa nova postura equivalia a "enfrentar o mundo como ele é, e não mais viver na ilusão de que estamos protegidos simplesmente pelo escrito da Doutrina Monroe". Cf. HART, 1915.
}

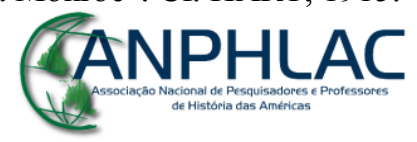

Revista Eletrônica da ANPHLAC, ISSN 1679-1061, №. 22, p. 202-230, Jan./Jun., 2017.

http://revista.anphlac.org.br 
Estados Unidos, por contraste - podem ser lidos como uma resposta a tal conjuntura, obviamente propiciando argumentos para a posição intervencionista.

Quanto à apropriação do artigo realizada por Veríssimo, é de se destacar, primeiramente, a explícita intenção de utilizar as reflexões do estadunidense sobre o México como arsenal para sua crítica à política brasileira. Ainda assim, chama a atenção que o brasileiro tenha optado, nesse caso, em tomar como base para seu posicionamento crítico uma argumentação alicerçada em critérios de tipo racial e permeada por uma perspectiva enaltecedora dos Estados Unidos. Na realidade, essa opção não aparece como um caso isolado quando observamos o tom bem mais conservador assumido pelo intelectual brasileiro frente aos rumos tomados pela Revolução no México, inclusive no que dizia respeito à intervenção estadunidense, como veremos mais à frente.

Nesse sentido, é significativo notar que a mudança de perspectiva assumida por Veríssimo se expressou até mesmo no que dizia respeito ao seu reconhecimento de uma autoridade discursiva a respeito dos assuntos mexicanos. Se, num primeiro momento, o brasileiro evocou a leitura crítica de Turner enquanto "uma autoridade em questões mexicanas, por ter estudado o país de primeira mão", pouco tempo depois podemos vêlo legitimar o discurso de Hart sem remetê-lo a qualquer relação com conhecimentos diretos sobre a realidade mexicana. Veríssimo o descreve como um "historiador [que], além de uma boa História dos Estados Unidos e vários estudos e monografia dessa história, tem dirigido importantes publicações históricas." (VERÍSSIMO, O Imparcial, 13/09/1913, p. 2 e 01/02/1914, p. 2)

\section{Revolução Mexicana e identidade latino-americana}

De uma maneira geral, as intervenções públicas de José Veríssimo sobre a Revolução Mexicana demonstram que ele identificou o Brasil com uma América "latina" cujos traços principais eram precisamente aqueles que tanto afligiam o México: desigualdade social e autoritarismo político. Destacou, nesse sentido, que a situação mexicana era "um espetáculo exemplar" para o continente, pois mostrava que somente a efetivação de uma reforma social - o que considerava urgente para todos os países latino-americanos - poderia garantir, a longo prazo, a estabilidade e o desenvolvimento desses países e evitar, assim, o caos revolucionário.

\section{GANPHLAC}

Revista Eletrônica da ANPHLAC, ISSN 1679-1061, №. 22, p. 202-230, Jan./Jun., 2017.

http://revista.anphlac.org.br 
Ao considerar a situação do México, inicialmente inspirado pelas análises de Turner, Veríssimo chegou a defender a reforma agrária. Mas o que podemos depreender da leitura do conjunto de seus artigos sobre o México é que o único caminho vislumbrado por ele como legítimo para a transformação social seria a ação de um poder político central, democraticamente eleito. Por mais que veiculasse uma crítica contundente às elites, em momento algum Veríssimo chegou a considerar que as classes populares por si próprias poderiam conquistar as reformas sociais que ele mesmo julgava como necessárias.

Tal posição foi explicitamente manifestada pelo intelectual brasileiro quando da ascensão dos exércitos populares na Revolução Mexicana. Nesse contexto, Veríssimo considerou que o caos político havia se instalado no México e que o país se transformara "numa espécie de fazenda disputada por vários bandoleiros". Entre esses, a ênfase foi colocada na figura do líder popular nortista: “[Pancho] Villa é, no rigor da palavra, um bandido, que ainda há pouco capitaneava uma quadrilha de salteadores." VERÍSSIMO, O Imparcial, 24/04/1914, p. 2) Em meio a tal conjuntura e na iminência de o país revolucionário vir a ser controlado por aqueles que considerava como "bandidos", o brasileiro chegou a defender a intervenção dos Estados Unidos no conflito mexicano. E não apenas defendeu a intervenção no México como acrescentou: “confesso que, na qualidade de cidadão de uma república latino-americana, não deixaria de estimar que os nossos sempre possíveis tiranos se receassem ao menos de uma intervenção do big stick.” (VERÍSSIMO, O Imparcial, 06/06/1914, p. 2)

Essa polêmica afirmação de Veríssimo foi desferida em meio a um intenso debate sobre as relações continentais e particularmente sobre a política estadunidense para o continente. Este era um tema candente nos debates intelectuais brasileiros no período, tendo em vista a perspectiva de uma maior aproximação entre o Brasil e a potência continental, postura que era defendida pelo ministro Lauro Müller, que ascendera ao Ministério de Relações Exteriores em 1913, após a morte do Barão do Rio Branco. ${ }^{12}$ Em meio a esse cenário, a atitude intervencionista dos Estados Unidos no México acabou intensificando fortemente os debates.

\footnotetext{
12 A posição oficial da diplomacia brasileira gerou intensos debates entre a intelectualidade, sendo considerada por muitos como perigosa, em face da agressiva política externa dos Estados Unidos no continente. Entre os intelectuais brasileiros, havia tanto admiradores dos Estados Unidos - entre os quais se destacavam Joaquim Nabuco e Euclides da Cunha - quanto os que, como Oliveira Lima, consideravam
}

\section{GANPHLAC}

Revista Eletrônica da ANPHLAC, ISSN 1679-1061, №. 22, p. 202-230, Jan./Jun., 2017.

http://revista.anphlac.org.br 
José Veríssimo, ao se manifestar sobre o intervencionismo estadunidense no continente, inicialmente encontrou a explicação para o "imperialismo yankee" no "temperamento prático" dos estadunidenses, fator que atribuiu explicitamente à sua identificação com a “estirpe germânica”. (VERÍSSIMO, O Imparcial, 06/11/1913, p. 2) Tratava-se, a princípio, da mesma interpretação culturalista do fenômeno imperialista que era compartilhada por boa parte da intelectualidade continental no período e que, como mostrou Oscar Terán (1981), tornou-se a base do "primeiro anti-imperialismo latino-americano". No entanto, ao refletir sobre as possíveis razões que tornavam viável a atitude agressiva por parte da potência continental, Veríssimo se afastou dessa explicação de fundo cultural e maniqueísta - que pressupunha uma oposição essencial entre "latinos" e "saxões" - para identificar a incapacidade das elites governantes latinoamericanas como o cerne dos problemas continentais.

Apesar de considerar a atitude dos Estados Unidos em relação ao México como "um grande atentado internacional" e afirmar que "foram manifestadamente os seus interesses econômicos e financeiros [...] que os levaram a ali intervir", o intelectual brasileiro destacou que a pretensão estadunidense de "superintendência da América" resultava da atitude das elites governantes dos países do continente, às quais acusou de serem as responsáveis pela "desgraçada situação da ordem moral e política da maioria dessas nações", além de se prestarem a uma "admissão tácita ou formal da doutrina de Monroe." (VERÍSSIMO, O Imparcial, 06/11/1913, p. 2) Em sua perspectiva, até mesmo a mediação diplomática sul-americana no conflito entre México e Estados Unidos - proposta por Argentina, Brasil e Chile, em 1914, após a invasão do porto mexicano de Vera Cruz por marines estadunidenses - era um exemplo da posição que criticava. $^{13}$

O fato essencial, na interpretação de Veríssimo, era que "o ABC punha-se ao lado dos Estados Unidos para regular a vida interna do México.” Tendo em vista a instabilidade política mexicana e a posição internacional alcançada pelos Estados Unidos, argumentou que, no âmbito das negociações em torno do conflito, certamente o

a potência continental como um perigo imperialista. Uma análise a respeito desse debate pode ser encontrada em BAGGIO, 1998.

13 Atuando enquanto um "bloco diplomático", Argentina, Brasil e Chile propuseram-se a mediar o conflito entre os países do norte, imediatamente após a intervenção militar estadunidense no México revolucionário em 1914, numa ação que ficou conhecida como mediação do ABC. Sobre a atuação do bloco diplomático e as discussões que suscitou entre a intelectualidade brasileira, cf. DIAS, 2015, p. 5869.

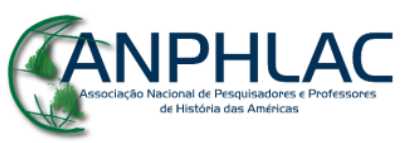

Revista Eletrônica da ANPHLAC, ISSN 1679-1061, №. 22, p. 202-230, Jan./Jun., 2017.

http://revista.anphlac.org.br 
país revolucionário teria "menos unidade e firmeza nos seus propósitos, e menos autoridade nas suas razões". Portanto, concluiu:

\begin{abstract}
A mediação ou fracassará completamente, o que é mais provável, ou se decidirá pelos Estados Unidos. Deem a cor que quiserem a essa [mediação]: em suma ela redunda no reconhecimento pelos três principais países da América Latina da competência de os Estados Unidos intervirem nos negócios internos das desgovernadas nações do continente. É legitima essa competência e será salutar essa intervenção? That is the question. (VERÍ́SSIMO, O Imparcial, 06/06/1914, p. 2) ${ }^{14}$
\end{abstract}

Dessa forma, a crítica de José Veríssimo voltava-se contra as elites latinoamericanas, desviando-se da tendência mais comum de concentrar o cerne da questão continental no "perigo imperialista". A propósito desse tema, o brasileiro também criticou duramente uma posição - ou pelo menos um discurso - que se firmava entre parte das elites intelectuais latino-americanas em face do "perigo yankee": o ideal de união latino-americana baseado numa suposta identidade cultural comum entre os países "latinos" da América. Como bom conhecedor da literatura hispano-americana, o brasileiro partiu de seu próprio métier da crítica literária para desenvolver uma ampla e incisiva argumentação contrária ao discurso latino-americanista, principalmente no que se referia a seus desdobramentos políticos.

Sobre esse assunto, e para o tema que nos ocupa neste artigo, o principal elemento a ser destacado das análises de Veríssimo é a relação que ele percebeu existir entre a intervenção dos Estados Unidos no México e o fortalecimento do latinoamericanismo. Escrevendo em 1914, asseverou: "fornec[ia]-lhe agora mais um argumento a presente atitude dos Estados Unidos contra o México." (VERÍSSIMO, $O$ Imparcial, 16/05/1914, p. 2) O intelectual brasileiro considerava que a intervenção dos Estados Unidos no país revolucionário convertia-se em um fator de intensificação de um processo, que já se encontrava em marcha, de formulação de uma identidade político-cultural de caráter continental e sentido defensivo, anti-norte-americana e antiimperialista.

Essa temática foi mais explicitamente tratada por Veríssimo em um artigo intitulado Um estado da alma argentina. À primeira vista, o texto dizia respeito simplesmente à literatura do país vizinho, mais especificamente à obra El solar de la raza, então recentemente publicada por Manuel Gálvez. No entanto, desde o início de

\footnotetext{
${ }^{14}$ Uso da expressão em inglês no original.

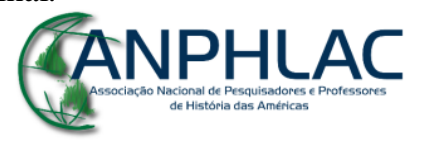

Revista Eletrônica da ANPHLAC, ISSN 1679-1061, №. 22, p. 202-230, Jan./Jun., 2017.

http://revista.anphlac.org.br
} 
sua explanação, Veríssimo enfatizou que o elogio da latinidade proposto pelo argentino fazia parte de um amplo "movimento das ideias de nossos vizinhos", fruto de importantes "estudos históricos e sociológicos" desenvolvidos por toda uma gama de hispano-americanos, entre os quais mencionou Francisco García Calderón, Rufino Blanco Fombona, José Ingenieros e Manuel Ugarte, entre outros. O brasileiro se ressentiu de não haver nada parecido no Brasil, em comparação com a qualidade desses estudos, que definiu como uma "obra séria, meditada, produto de fortes estudos originais e de uma alta cultura, geralmente feita nos melhores centros europeus", os quais eram englobados sob a "definição imprecisa" de modernismo, identificado por ele como "uma dupla reviviscência de idealismo e do nacionalismo, concomitantemente". (VERÍSSIMO, O Imparcial, 16/05/1914, p. 2)

Mas, na mesma medida em que reconheceu a importância desses estudos, Veríssimo também criticou o substrato - "subconsciente" foi a expressão utilizada dessas interpretações e alertou para o fato de que essas ideias, a princípio relativas ao universo cultural, também "pod[ia]m influir na política". Em sua concepção, todo esse movimento de ideias externava um "estado interessantíssimo da alma hispanoamericana", marcado por um conjunto de "idealismo, nacionalismo, emulação dos Estados Unidos [e] reação hispanófila", derivado do ferido "orgulho espanhol desses povos" diante da "intuição de que [...] a poderosíssima nação do Norte, por sua mesma desmedida grandeza e poderio é, para as demais nações do continente, uma perene ameaça". Assim, no intuito de contrapor o perigo estadunidense, esses países "de curto passado e escassas tradições" recorriam à "ilusão do sentimento latino" para se "contrapor à grandeza norte-americana" e "exagera[va]m-se as próprias faculdades", presumindo-se "herdeiros forçados da obsoleta grandeza espanhola". (VERÍSSIMO, $O$ Imparcial, 16/05/1914, p. 2)

Da perspectiva do brasileiro, esse era precisamente "o rasgo que defin[ia] a mentalidade latina comparada com a anglo-saxônica", posto que "os americanos do norte s[eriam] grandes por si mesmos", pois "desdenha[va]m recorrer ao passado para aumento do [seu] próprio patrimônio e valimento." Quanto a "nós, latino-americanos", sentenciava, "não nos podemos enganar da nossa própria presunção patriótica" e "cremos ingenuamente aumentar-lha recorrendo aos fastos dos nossos antepassados ibéricos." Essa estratégia, em sua visão, só conseguia “provar a nossa imbecilidade" e

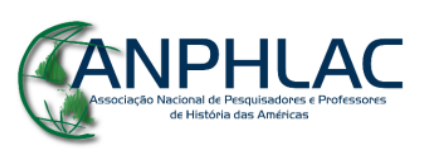

Revista Eletrônica da ANPHLAC, ISSN 1679-1061, №. 22, p. 202-230, Jan./Jun., 2017.

http://revista.anphlac.org.br 
era "um péssimo expediente", um "estímulo artificial, que só pode[ria] obrar em algum espírito mais ou menos místico, [...] propenso às sentimentalidades", como identificava ser o caso do escritor argentino Manuel Gálvez. (VERÍSSIMO, O Imparcial, 16/05/1914, p. 2)

Veríssimo contrariava, assim, as mais idealistas visões de que um suposto passado "latino" fornecia os vínculos de união da grande maioria das repúblicas do continente e as predestinaria a um lugar de oposição frente ao colosso do norte baseada em sua distinta origem cultural. O brasileiro criticou sutilmente o "entusiasmo" latinista que sustentava semelhante argumentação como uma espécie de doença. Destacou que o “entusiasmo já e[ra] em si um estado anormal”, atribuindo assim, indiretamente, a uma moléstia ou "estado da alma" o que identificou como um tipo de revanchismo hispanista frente à ascensão norte-americana, que considerava inquestionável. (VERÍSSIMO, $O$ Imparcial, 16/05/1914, p. 2) Mas o foco de sua argumentação anti-latino-americanista era predominantemente a política.

Em um artigo publicado após a intervenção militar dos Estados Unidos no México, Veríssimo relacionou explicitamente e de maneira crítica o fervor latinoamericanista no continente à atitude da potência continental para com o México revolucionário. Citou La Revista de América, que era editada por hispano-americanos em Paris, como uma publicação que "brilhantemente representa[va] a inteligência e a cultura latino-americana" na Europa, mas criticou seu editorial intitulado "La guerra inicua”, no qual se dirigia um ataque ao presidente Wilson pela intervenção no México, e posicionou-se contra a argumentação da revista sobre o efeito continental da ação estadunidense. Segundo Veríssimo, La Revista de América identificava a intervenção dos Estados Unidos no México revolucionário como um "humilhante imperialismo" que "provoca[va] em todas as repúblicas do Novo Mundo o mais indignado protesto." Contra tal posição hispano-americana, o intelectual brasileiro desferiu uma cáustica e incisiva crítica, nos seguintes termos:

Parece-me lícito duvidar da unanimidade ou pelo menos da força dessa reprovação [à atitude dos Estados Unidos]. Nada mais comum do que atribuirmos a outrem os nossos próprios sentimentos. [...] Os escritores hispano-americanos de educação e vida europeia podem enganar-se emprestando aos seus povos as suas próprias paixões anti-norte-americanas, e certamente enganam-se quando lhes atribuem manifestações que supõem coletividades mais conscientes do que são as latino-americanas. Salvo se num caso particular como este, houvermos de aceitar como seus legítimos

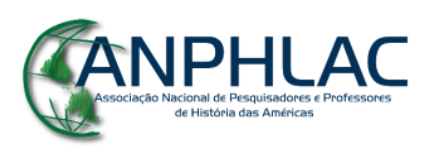


representantes alguns jornalistas e escritores. No Brasil creio não enganarme, não temos por via de regra nem a "ilusão americana", no sentido do opúsculo de Eduardo Prado, nem no mais compreensivo de panamericanismo integral. [...] Em todo caso, a nossa situação de América é, digamos assim, uma situação à parte. Nem estamos, como o México sob o 'grande patriota' Porfirio Díaz debaixo da influência dos Estados Unidos, nem comungamos no ibero-americanismo preconizado pelos intelectuais hispano-americanos. (VERÍSSIMO, O Imparcial, 06/06/1914, p. 2)

Ao lançar por terra o esmerado edifício culturalista da identidade latinoamericana, Veríssimo pretendia afastar a possibilidade de que a posição anti-norteamericana servisse para ofuscar a má conduta das elites governantes do continente. $\mathrm{O}$ brasileiro não deixou de explicitar claramente esse objetivo ao afirmar que a única possibilidade de defesa para a América Latina frente ao "monroísmo wilsoniano" estaria, não no entusiasmo latino-americanista, mas no "abandono completo do regime de desordem e ilegalidade em que a têm conservado, menos os seus povos civicamente incapazes, que os seus governantes, em [sua] maioria indignos". (VERÍSSIMO, $O$ Imparcial, 06/06/1914, p. 2)

Nesse sentido, pensamos que, em certa medida, a posição assumida pelo educador e crítico literário brasileiro frente ao discurso identitário latino-americanista pode ser relacionada ao "realismo" característico de suas reflexões políticas, conforme explicitado por João Alexandre Barbosa, analista de sua obra. (BARBOSA, 1974) No entanto, acreditamos que outros elementos decorrentes da argumentação de Veríssimo sobre as temáticas continentais são tão ou mais relevantes e reveladores do que o realismo dessas análises.

O primeiro deles é o fato de que ele, explicitamente, confere ao Brasil "uma situação à parte" dentro do continente, a qual afastava nosso país da reivindicação de uma identificação ibero ou latino-americana, tal como proposta por intelectuais hispanoamericanos. Sobre esse tema, aliás, salta aos olhos o fato de que em sua crítica políticoliterária do movimento latino-americanista, apesar de citar elogiosamente Ugarte e Ingenieros, por exemplo, Veríssimo preferiu se deter, aprofundar e amplificar como representativo desse amplo e multifacetado movimento de ideias uma faceta bem mais conservadora, representada pelo livro do argentino Manuel Gálvez, conforme mencionado anteriormente.

Tal exposição do ideário latino-americanista que envolvia os hispanoamericanos somada às ácidas críticas que desferiu ao mesmo assunto no contexto dos

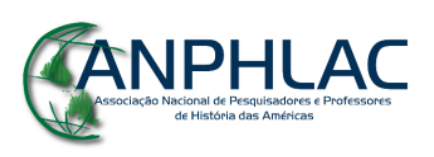

Revista Eletrônica da ANPHLAC, ISSN 1679-1061, №. 22, p. 202-230, Jan./Jun., 2017.

http://revista.anphlac.org.br 
conflitos entre os Estados Unidos e o México revolucionário faziam com que, no conjunto de sua argumentação, o latino-americanismo e a solidariedade continental fossem desqualificados como alternativas identitárias para o Brasil. O peso de tal interpretação no cenário intelectual brasileiro não deve ser desprezado, tendo em vista que José Veríssimo era um dos poucos críticos literários do país que se dedicava sistematicamente à produção cultural hispano-americana.

Há, ainda, outro elemento importante deixado sutilmente, e talvez mesmo inconscientemente, na leitura da situação continental realizada por Veríssimo: enquanto o latino-americanismo era ofuscado, deixando, assim, de funcionar como um referencial para o Brasil, eram os Estados Unidos que se erigiam como parâmetro. As análises do intelectual brasileiro sobre o continente acabaram esbarrando na idealização do colosso do norte sempre que esse era confrontado com as realidades latino-americanas, entre elas a faceta popular da Revolução Mexicana, frente a qual Veríssimo não apenas aceitou como chegou a defender o big stick estadunidense. Exatamente na sequência de sua defesa da intervenção estadunidense no México revolucionário, concluiu, sem deixar espaço para dúvidas, sua posição sobre as "intervenções civilizatórias" no continente:

\footnotetext{
Quem sabe nisso [nas intervenções] não estaria a solução do problema da ordem política das repúblicas sul-americanas? Aliás, o que estão fazendo os Estados Unidos com o México, com bem pouca diferença já fez o Brasil, sob a monarquia, com as Repúblicas do Prata, e não é esse um dos nossos feitos que menos nos honram. Foi a nossa ação, acabando ali à viva força, com decidida intervenção na sua política interna, que preparou o estado de ordem e progresso de que gozam a Argentina, o Uruguai e mesmo o Paraguai, depois que exterminamos os Rosas, os Aguirres e os López e destruímos os odiosos regimes que representavam. (VERÍSSIMO, $O$ Imparcial, 25/04/1914, p. 2)
}

A passagem acima é bastante ilustrativa de como as análises de José Veríssimo sobre o continente, apesar de expressarem uma maior sofisticação teórica, na realidade, em pouco se diferiam de certas interpretações mais rasteiras sobre a "missão civilizadora" dos Estados Unidos na América e da percepção de que o Brasil ocuparia um status diferenciado no continente, devendo atuar, bem como a potência continental, como "agente civilizador". ${ }^{15}$ Tudo isso pode ser lido nas intervenções públicas de

\footnotetext{
${ }^{15}$ Essa mesma perspectiva aparece no posicionamento assumido por alguns órgãos da grande imprensa brasileira ao tratar do conflito entre os Estados Unidos e o México revolucionário e a decorrente mediação do ABC. Na ocasião, os editores do jornal carioca Gazeta de Notícia, por exemplo, publicaram
}

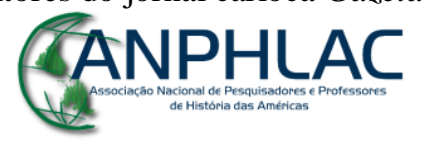

Revista Eletrônica da ANPHLAC, ISSN 1679-1061, №. 22, p. 202-230, Jan./Jun., 2017.

http://revista.anphlac.org.br 
Veríssimo, a despeito das fortíssimas críticas que ele desferiu às elites políticas nacionais.

Como um contraponto, não deixa de ser interessante comparar a perspectiva de Veríssimo com a posição assumida por Oliveira Lima na mesma conjuntura. A considerar a visão deste último sobre a evolução histórica do continente, que colocava a "América inglesa" numa condição social, cultural e racial de superioridade em relação à "latina"16, era de se supor que semelhante compreensão do continente conduzisse à justificação de uma posição intervencionista por parte dos Estados Unidos. Mas, ao contrário disso, e em coerência com o conjunto de sua obra, Oliveira Lima considerou que, em hipótese alguma, a superioridade estadunidense poderia lhe conceder o direito de intervir em outros países, ação para a qual não se poderia atribuir outro nome a não ser "imperialismo" e outra posição a não ser o repúdio. Dessa forma, quando o presidente Wilson desferiu seu ultimado ao ditador mexicano, Huerta, Oliveira Lima, em artigo publicado no jornal $O$ Estado de São Paulo (OESP), expressou a seguinte leitura da situação:

a América Latina desconfia das lições de moral do presidente Wilson não menos do que das arremetidas sociológicas do presidente Roosevelt. $\mathrm{O}$ México está tomando aspecto de vítima e Huerta - quem diria? - de cordeiro perseguido pelo lobo yankee. (OLIVEIRA LIMA, OESP, 10/11/1913, p. 3)

Veríssimo, por sua parte, após a invasão do porto mexicano de Vera Cruz por marines estadunidenses, considerou que o reconhecimento do ditador Huerta pelos Estados Unidos poderia ter evitado o conflito. Novamente, sua posição se baseava em análises estadunidenses. Nesse caso, um editorial de The North American Review (TNAR) que trazia um "apelo" ao presidente Wilson pelo reconhecimento do "governo de fato" de Huerta. Nesse artigo, os revolucionários foram descritos como "hordas de

um editorial em que não apenas culpavam o México pelo conflito internacional, como argumentavam que os "erros" mexicanos decorriam do temperamento passional de seus caudilhos, o que justificaria a intervenção de uma nação "racional", capaz de resolver a situação interna do país. A atuação do ABC foi enquadrada nesse esquema, sendo exaltada nas páginas da Gazeta como "uma grande vitória americana a da razão pela atitude moral do continente contra os ímpetos patrióticos". Na argumentação do jornal, as "potências do sul", movidas pelos mesmos atributos "morais" e "racionais" que os Estados Unidos, colaboravam com a potência do norte na tarefa de civilização do continente. (Gazeta de Notícias, 28/04/1914, $1^{\text {a }}$ pág.).

${ }^{16}$ As concepções de Manoel de Oliveira Lima sobre o continente foram expressas de forma sistemática em uma série de conferências que proferiu, entre 1912 e 1913, em universidades dos Estados Unidos e do Brasil, as quais foram reunidas e publicadas pela Livraria Garnier sob o título de América Latina e América Inglesa: a evolução brasileira comparada com a hispano-americana e com a anglo-americana.

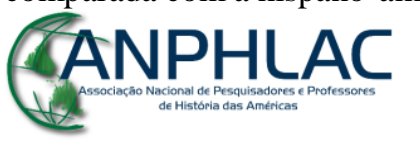

Revista Eletrônica da ANPHLAC, ISSN 1679-1061, №. 22, p. 202-230, Jan./Jun., 2017.

http://revista.anphlac.org.br 
bandidos opositores", enquanto o ditador mexicano, recorrentemente referido como "the old Indian", foi identificado como "correta ou incorretamente, a única esperança para o México" e "a única força capaz de manter a ordem” no país. (TNAR, vol. 199, no 701, abril de 1914, p. 498-500)

Tomando tal perspectiva como base, Veríssimo se manifestou sobre o assunto afirmando que, se os Estados Unidos tivessem reconhecido Huerta, “embora assassino", o que - ressaltou com seu realismo característico - "não er[a] nenhuma exceção nas Repúblicas ibero-americanas", poderiam ter usado os "recursos de sua diplomacia" para “tirar dele algo de bom para o seu país." (VERÍSSIMO, O Imparcial, 25/04, 1914, p. 2) Dessa forma, o intelectual brasileiro acabava por reconhecer que um governo ditatorial, devidamente pressionado pela diplomacia estadunidense, poderia gerar "algo de bom" para o México.

Essa posição não soa estranha quando observamos que José Veríssimo a assumiu tomando como referência um artigo representativo da visão antirrevolucionária de corte neoporfirista que era sustentada por uma parcela da opinião pública estadunidense a respeito da situação do México. O editorial citado pelo intelectual brasileiro "apelava" ao presidente Wilson não apenas para que reconhecesse o ditador mexicano, mas também para que proibisse a venda de armas aos "rebeldes" daquele país, ação que, segundo tal perspectiva, seria uma "resposta às demandas de humanidade e civilização." (TNAR, vol. 199, nº 701, abr. 1914, p. 498-500)

\section{Sobre o "realismo" de Veríssimo: algumas considerações}

As reflexões sobre a eclosão do movimento revolucionário e os marcantes episódios dos primeiros anos da revolução no México levaram o educador e crítico literário brasileiro a se manifestar sobre temas políticos e sociais fundamentais, tais como as relações entre transformação social, atuação popular e o caráter dos regimes políticos. Essas temáticas ganharam densidade ainda maior ao serem, com o desenrolar dos acontecimentos, inseridas no complexo quadro das relações continentais, dentro do qual ganhava centralidade a questão da identidade brasileira no continente.

Como procuramos evidenciar ao longo do texto, ao mesmo tempo em que as intervenções públicas de José Veríssimo sobre o México revolucionário estiveram

\section{GANPHLAC}

Revista Eletrônica da ANPHLAC, ISSN 1679-1061, №. 22, p. 202-230, Jan./Jun., 2017.

http://revista.anphlac.org.br 
associadas ao debate mais amplo, de caráter transnacional, sobre o significado da experiência revolucionária mexicana, suas análises sobre o tema conectaram-se fortemente aos debates político-intelectuais locais, travados no cenário brasileiro, em relação aos quais o intelectual fez questão de manifestar explícita e enfaticamente suas posiçõos.

Derivados desse contexto argumentativo, os artigos de Veríssimo sobre a Revolução Mexicana foram expressos na forma típica da polêmica, um discurso direcionado ao "combate de ideias" e que supõe a existência de um outro, contrário, ao qual se remete, embora não necessariamente de maneira explícita. Conforme a definição do historiador e crítico literário belga-canadense Marc Angenot, trata-se de um "discurso de ideias de caráter persuasivo", que visa o convencimento a partir da "dupla estratégia" de demonstrar uma tese e, ao mesmo tempo, refutar/desqualificar a contrária. Uma escrita que acaba sendo marcada por uma "ambiguidade essencial", já que "é, ao mesmo tempo, uma busca da verdade, ou ao menos do opinável [...], mas também um ato [discursivo] que supõe uma presença forte e explícita do enunciador na enunciação.” (ANGENOT, 1982, p. 34-5)

Sobre essa "presença” de José Veríssimo em seus artigos sobre a Revolução Mexicana, queremos destacar alguns elementos. O primeiro deles é, sem dúvida, sua preferência pela produção estadunidense, quer fosse a imprensa ou o discurso acadêmico. Em parte, isso pode ser explicado pela dificuldade de acesso direto a fontes mexicanas, tendo em vista o próprio cenário de guerra civil no país, além da ausência, por exemplo, de enviados especiais de jornais brasileiros que cobrissem os conflitos no México. Nesse sentido, certamente, o fato de Veríssimo recorrer, em um primeiro momento, ao artigo de John Kenneth Turner, tinha relação com a importância, inclusive internacional, assumida pelas denúncias do jornalista estadunidense no contexto do início do movimento revolucionário mexicano.

Mas não podemos perder de vista que tanto a recorrência no uso de fontes estadunidenses quanto o perfil cada vez mais conservador apresentado pelas publicações, autores e argumentos utilizados pelo intelectual brasileiro para embasar suas reflexões sobre o México revolucionário foram frutos de uma escolha realizada por ele - inclusive dentro da multifacetada produção estadunidense - o que, portanto, não deixa de ser revelador de sua posição.

\section{CANPHLAC}

Revista Eletrônica da ANPHLAC, ISSN 1679-1061, №. 22, p. 202-230, Jan./Jun., 2017.

http://revista.anphlac.org.br 
Se, por um lado, podemos concordar com João Alexandre Barbosa no que diz respeito ao "realismo" como um traço característico das argumentações de Veríssimo, por outro lado, a análise de seus artigos sobre o México revolucionário também permite perceber as limitações dessa perspectiva. Muito embora o educador e crítico literário brasileiro afirmasse não padecer da "ilusão americana", não encontramos em suas reflexões sobre os Estados Unidos o mesmo "realismo" com o qual observava e julgava a América Latina.

Assim, caberia concluir parafraseando o próprio Veríssimo quando, em um artigo sobre a atitude do presidente estadunidense para com o país revolucionário intitulado $O$ sr. Woodrow Wilson e o México, ou os inconvenientes da virtude - lançou mão de um refrão em francês ${ }^{17}$, carregando na ironia - outro traço marcante de seu discurso -, para defender que o chefe da Casa Branca deveria se abdicar um pouco de suas tão afamadas virtudes democráticas e reconhecer o ditador mexicano, Huerta. Na ocasião, o intelectual brasileiro orientava, citando o referido refrão: “é necessário virtude, mas virtude demais não é necessário"; ao que poderíamos evocar os “inconvenientes" de seu realismo para nos lembrar que o realismo é necessário, mas realismo em tudo é o necessário.

\section{Fontes e Referências Bibliográficas}

ALTAMIRANO, Carlos. Elites culturales en el siglo XX latinoamericano. In: ALTAMIRANO, Carlos (Ed.). Historia de los intelectuales en América Latina II. Los avatares de la "ciudad letrada" en el siglo XX. Buenos Aires: Katz, 2010.

. Para un programa de historia intelectual y otros ensayos. Buenos Aires: Siglo XXI, 2005.

. Intelectuales: notas de investigación. Bogotá: Grupo Editorial Norma, 2006.

ANGENOT, Marc. La parole pamphlétaire. Typologie des discours modernes. Paris: Payot, 1982.

BAGGIO, Kátia Gerab. A “outra” América: a América Latina na visão dos intelectuais brasileiros das primeiras décadas republicanas. Tese de Doutorado. São Paulo: Departamento de História, FFLCH, USP, 1998, 224 p.

\footnotetext{
${ }^{17}$ José Veríssimo iniciou o referido artigo com o seguinte refrão em francês: Faut de la vertu, pas trop n'en faut. (VERÍSSIMO, O Imparcial, 25/04/1914, p. 2)
}

\section{GANPHLAC}


BARBOSA, João Alexandre. A tradição do impasse: linguagem da crítica e crítica da linguagem em José Veríssimo. São Paulo: Ática, 1974.

A vertente latino-americana. Apresentação de VERÍSSIMO, José. Cultura, literatura e politica. (Seleção e apresentação: João Alexandre Barbosa). São Paulo: Brasiliense, 1986, p. 7-14.

COSTA, Adriane Vidal. José Veríssimo: o sujeito e o espaço na construção da nação brasileira. Revista literária Paralelo 20, Belo Horizonte, v. 2, 2004, p. 35-46.

DIAS, Natally Vieira. A Revolução Mexicana nos debates político-intelectuais brasileiros: projeções, leituras e apropriações (1910-1941). Belo Horizonte: Departamento de História, PPGH/FAFICH/UFMG, 2015, 302 p.

. O México como "lição": a Revolução Mexicana nos grandes jornais brasileiros e argentinos (1910-1915). Dissertação de Mestrado. Belo Horizonte: Departamento de História, PPGH/FAFICH/UFMG, 2009, 175 p.

Gazeta de Notícias, Estados Unidos-México (editorial), 1ª pág., 28/04/1914.

GOMES, Angela de Castro. A educação nacional: república e educação patriótica. In: A República, a História e o IHGB. Belo Horizonte: Argumentum, 2009, p. 99-105.

HART, Albert Bushnell. Mexico and the Mexicans. The World's Work, no 3, jan., 1914. . Roosevelt as a pionner. Prefácio a The Works of Theodore Roosevelt. Memorial Edition. Volume X. Nova York: Charles Scribner's Sons, 1924, p. XXIX. Disponível em: http://www.theodore-roosevelt.com/images/research/worksoftheodoreroosevelt/TRMEMORIALWORKS10.pdf Acesso em: 12/01/2014.

. Shall We Defend the Monroe Doctrine? The North American Review, vol. 202, $\mathrm{n}^{\circ} 720$, Nov. 1915.

La Prensa (Buenos Aires), La situación mexicana (editorial), 19/05/1911, p. 11.

MEYER, Eugenia. El encuentro, los encuentros. Introdução a John Kenneth Turner: periodista de México. México: Era: Facultad de Filosofía y Letras, UNAM, 2005, p. 9104.

MOUILLAUD, Maurice. Da forma ao sentido. In: MOUILLAUD, Maurice; PORTO, Sérgio Dayrell (Orgs.). O jornal, da forma ao sentido. Brasília: Paralelo 15, 1997, p. 2935 .

MOURA, Gerson. História de uma história: rumos da historiografia norte-americana no século XX. São Paulo: Edusp, 1995.

\section{GANPHLAC}

Revista Eletrônica da ANPHLAC, ISSN 1679-1061, №. 22, p. 202-230, Jan./Jun., 2017.

http://revista.anphlac.org.br 
OLIVEIRA LIMA, Manoel de. A situação do México, "Coisas Estrangeiras", O Estado de São Paulo, 27/05/1911, p. 3.

. Novos desenvolvimentos da doutrina Monroe, "Coisas Estrangeiras", O Estado de São Paulo, 10/11/1913, p. 3.

SKINNER, Quentin. Lenguaje, política e historia. Buenos Aires: Quilmes, 2002.

TERÁN, Oscar. El primer antiimperialismo latinoamericano. Punto de Vista. Revista de Cultura, Buenos Aires, ano IV, n. 12, jul-oct, 1981, p. 3-10.

The North American Review, vol. 199, no 701, abril de 1914, p. 498-500. Disponível em: http://www.unz.org/Pub/NorthAmericanRev-1914apr-00481?View=PDF Acesso em: $12 / 12 / 2013$.

TURNER, John Kenneth. Mexico's Bandit Armies. The National Weekly, abril de 1913. In: MEYER, Eugenia. John Kenneth Turner: periodista de México. México: Era: Facultad de Filosofía y Letras, UNAM, 2005, p. 205-210.

. US Navy Aids Wall Street Pirates. Appeal to Reason, 08/11/1913. In: MEYER, Eugenia. John Kenneth Turner: periodista de México. México: Era: Facultad de Filosofía y Letras, UNAM, 2005, p. 230-40.

VERÍSSIMO, José. O caso do México. O Imparcial, 19/09/1913, p. 2.

. Estados Unidos e México: um grande atentado internacional, O Imparcial, 06/11/1913, p. 2.

- O Sr. Woodrow Wilson e o México ou os inconvenientes da virtude, $O$ Imparcial, 25/04/1914, p. 2.

. Um estado da alma argentina, O Imparcial, 16/05/1914, p. 2.

. O monroísmo wilsoniano e a América Latina, O Imparcial, 06/06/1914, p. 2. . A educação nacional [1890]. $4^{\mathrm{a}}$ edição. Rio de Janeiro: Topbooks/ PUC Minas, 2013.

YANKELEVICH, Pablo. En la retaguardia de la Revolución Mexicana: Propaganda y propagandistas mexicanos en América Latina, 1914-1920. Boletín Americanista, Universidade de Barcelona, $\mathrm{n}^{\mathrm{o}}$ 49, 1999, p. 266. Disponível em: http://dialnet.unirioja.es/servlet/listaarticulos?tipoDeBusqueda=ANUALIDAD\&revista $\underline{\text { DeBusqueda }=5730 \& \text { claveDeBusqueda }=1999}$ Acesso em: 05/06/2014.

\section{GANPHLAC}

Revista Eletrônica da ANPHLAC, ISSN 1679-1061, №. 22, p. 202-230, Jan./Jun., 2017.

http://revista.anphlac.org.br 